\title{
Psychosocial Risks
}

How Can the Past Contribute to Current Debates?

Les risques psychosociaux: quelles correspondances anciennes aux débats récents?

\section{Nicolas Hatzfeld}

\section{(2) OpenEdition}

Journals

\section{Electronic version}

URL: http://journals.openedition.org/travailemploi/6293

DOI: 10.4000/travailemploi.6293

ISSN: 1775-416X

\section{Publisher}

DARES - Ministère du Travail

\section{Printed version}

Date of publication: 15 December 2013

Number of pages: $33-43$

ISSN: 0224-4365

\section{Electronic reference}

Nicolas Hatzfeld, « Psychosocial Risks », Travail et Emploi [Online], Hors-série | 2013, Online since 01 January 2014, connection on 20 April 2019. URL : http://journals.openedition.org/travailemploi/6293 ; DOI : 10.4000/travailemploi.6293 


\title{
Psychosocial Risks -How Can the Past Contribute to Current Debates? ${ }^{(*)}$
}

\author{
Nicolas Hatzfeld ${ }^{(* *)}$
}

\begin{abstract}
The notion of psychosocial risk is relatively recent and has yet to be clearly defined. As no exact equivalent in the past has been found, historians need to exercise caution and avoid falling into the trap of anachronisms and analogies. Instead, they need to focus on how the parties involved perceive psychosocial risk. In this article, we shall examine how over two centuries the notion of risk took on a particular significance depending on specific events or periods. There is no standard approach to the topic of work-related risk and extra-professional risk-it does not correspond to any one phenomenon or a particular idea. Villermé vs. Taylorism, worker exhaustion vs. productivity... social policymakers, the State or experts provide us with elements of comparison which give us insight to the specific nature of this recent period which could be described as a labour crisis.
\end{abstract}

Psychosocial risks are, in historical terms, relatively unchartered territory. Current data on the subject reveals a lack of historical references, unlike many other human and social sciences for which there is abundant and growing data. This deficiency can be largely explained by the specific nature of the discipline. To start with, the very term "psychosocial risks" is recent, when referring to work situations at least. History is often less capable of reacting to new events and ideas than other social sciences which are more focused on the present. (1) The present is considered not so much as a subject for research -it tends to be seen as an incentive for renewed questioning of the past. The difference is perhaps heightened by a tendency, in France at least, to shift some social issues, especially those relating to labour, to the field of sociology. Finally, in this area, history has at last loosened the ties of its privileged relationship with the labour movement that tended to bias its approach to research topics. Research into occupational health, precisely, provides fresh focus for new perspectives and research. ${ }^{(2)}$

The above-mentioned caution is quite understandable. When historians work on past memories and records, they need to find situations that in the past correspond to this new phenomenon, namely, psychosocial risks. There is an additional complication: the terms and discourses used in the past

(*) Article published in French in Travail et emploi, $\mathrm{n}^{\circ}$ 129, janvier-mars 2012.

(**) University of Evry, LHEST-IDHE; nicolas.hatzfeld@ gmail.com

(1) See $n^{\circ} 10$ of the Nouvelle revue de psychosociologie, $2010 / 2$.

(2) This text benefits from a collective reflection between historians, notably on the notions of inaptitude and risk, as well as comparative perspectives. The text also benefits from careful proofreading from the editors of the review. did not have exactly the same meanings as today. What is more, the situations they were used for are no longer the same. Issues relating to psychosocial risks affect current organizations. Whether we are talking about companies or public organizations, industries or services, the definition of psychosocial risks is very far from those used fifty, a hundred or more years ago, and even more unfamiliar to us. Utmost caution must be exercised when comparing the activities and techniques used, the hierarchical relations, the types of contracts and remuneration of work -above all when all of these factors converge in very specific context or era. Not only does the risk of anachronism concern workers and employers and those directly involved in work and employment relations, it also concerns the legislative, legal and administrative action of the State, not to mention scientific knowledge in medicine, psychology and in social sciences.

So, if caution prevents us from extrapolating current models onto past situations, it is nonetheless difficult to avoid drawing parallels with contemporary issues. Without a doubt, the notion of risk and the way debates on this subject are developing in society are at the heart of these similarities. This is what encourages us to look for historical bearings, in parallel with research already conducted from sociological or psychological perspectives. The notion of risk itself is subject to various definitions, even controversies. ${ }^{(3)}$ One of the most notable of these is the one given by the College d'Expertise concerning the monitoring of psychosocial risks at

(3) We draw attention in particular to the critique proposed by Yves Clot, who sees in the theme of psychosocial risks the justification of a restorative perspective, or a diversion before the essential question of a job well done. 
work. (4) Bearing in mind that the notion of risk refers "to the link between the exposure to risk factors on the one hand and damages on the other", the report suggests that "the idea that socio-economic factors, notably organizational ones, interact with the psyche of workers and that this confrontation has an impact on the mental, physical and social health of those workers". The report focuses on the necessity to clearly distinguish the factors and effects: the College believes that the study of factors makes sense itself, whereas the study of its effects entails careful and cautious interpretation. This deliberately broad definition covers past situations and standpoints. This does not make it any easier to draw parallels with the situations and standpoints of the present times.

\section{Questions of Approach}

Drawing these parallels presumes that there is a convergence of notions of risk, of psychopathologies and of the world of work. General health risks for the population have always been a subject for concern, as have been the controversies surrounding their causes, which were at the heart of the public health movement emerging in the $19^{\text {th }}$ century. ${ }^{(5)}$ In the same way, from the 1820 s onwards, various Court orders determined the safety measures and administrative inspections to which some factors of industrial risk (such as the use of steam) were to be subjected. (6) However, it was only gradually that occupational risk became an independent issue and its prevention a subject for debate. (7) Moreover, apparently research in psychiatry and psychology was used sporadically in the work environment during the development of these two

(4) Gollac M., Bodier M. (2011), Mesurer les facteurs psychosociaux de risque au travail pour les maîtriser, a report from the Collège d'expertise sur le suivi des risques psychosociaux au travail, Paris, Ministère du Travail, de l'Emploi et de la Santé, p. 223.

The document can be consulted (in French) at the following address: http://www.ladocumentationfrancaise.fr/var/storage/ rapports-publics/114000201/0000.pdf.

(5) Jorland G. (2010), Une société à soigner. Hygiène et salubrité publiques en France au XIXe siècle, Paris, Gallimard; Moriceau C. (2009), "Les perceptions des risques au travail dans la seconde moitié du XIX ${ }^{\mathrm{e}}$ siècle : entre connaissance, déni et prévention", Revue d'histoire moderne et contemporaine, vol $56 \mathrm{n}^{\circ}$ 1, pp. 12-28; Moriceau C. (2009), Les douleurs de l'industrie. L'hygiénisme industriel en France, 1860-1914, Paris, EHESS éditions.

From the $19^{\text {th }}$ century onwards, the mainstream review, Annales d'hygiène publique et de médecine légale, is the main one referred to.

(6) Chapuis C. (1983), "Risque et sécurité des machines à vapeur au XIX ${ }^{\mathrm{e}}$ siècle", Culture technique, ${ }^{\circ}{ }^{11}$, pp. 202-217.

(7) Viet V., Ruffat M. (1999), Le choix de la prévention, Paris, Economica. In 1924 the review of Annales d'hygiène publique, industrielle et sociale came out, followed by the Revue de médecine du travail (1929), Le travail humain (1933), Le médecin d'usine (1938) and the Archives des maladies professionnelles (1938). disciplines, notably in the second part of the $19^{\text {th }}$ century. However, the history of how these disciplines viewed work-related risks (as well as their indifference to this subject) has not been fully documented. ${ }^{(8)}$ We can quote for example, mental disorders and stress -whether resulting from railway accidents or from war situations, or even as the result of difficult working conditions for telephone operators- and how the approach to these changed from traumatic shocks to illnesses. This is one illustration of how these human sciences took occupational risks into consideration in the course of their own development. ${ }^{(9)}$

The text that follows must therefore take into account three discrepancies: firstly between the situations described, secondly, between those situations and their portrayal in historical records, and lastly, between these sources and the hindsight that history gives us today. Thus, we will borrow two questions on the subject from the aforementioned College of Expertise and use them as a reference: how are the risks run by workers on a psychological level formulated, and to which factors are they attributed? The answers to these questions focus as much on working conditions themselves as on the characteristics of the workers -be they personal or related to their living conditions. These evaluations did not always have the same format as in recent years and could appear to be different depending on the time and form. They came from a variety of sources, such as workers' and employers' direct statements as well as those made via representatives, but also from State employees (legislators, judges or civil servants working in the Ministry of Labour and Public Health), health experts and professionals, etc.

Workers and their representatives both tend to blame working conditions when the physical or mental health of workers is affected. They identify unreasonable or excessive demands and constraints as the main factor of these risks. ${ }^{(10)}$ These could take many different forms, notably pay cuts and the encouragement by manufacturers of increased competition among workers. These excesses certainly go back a long way. The exhaustion mentioned in different enquiries covers varied aspects in which the equivalents of stress or depression are barely distinguishable. Conversely, employers tend to highlight the unrest that workers

(8) Clot Y. (ed.) (1996), Les histoires de la psychologie du travail. Approche pluri-disciplinaire, Toulouse, Octares; Loriol M. (2000), Le temps de la fatigue. La gestion sociale du mal-être au travail, Paris, Anthropos.

(9) Loriol M. (2007), "La reconnaissance juridique du stress au travail", in Buscatto M., Loriol M. and WelLer J-M. (ed.), Au-delà du stress. Une sociologie des agents publics au contact des usagers, Toulouse, Eres, 2007, pp. 91-109.

(10) Cottereau A. (1983), "Usure au travail. Destins masculins et destins féminins dans les cultures ouvrières en France, au XIX ${ }^{\mathrm{e}}$ siècle", Le Mouvement social, n 124, pp. 82-83. 
create in their working environment and even more so in the organizations they belong to, due to their personal or social profiles, shaped by events outside their organizations. This bipolarization of positions regarding psychosocial risks seems to have irremediably shaped the analyses and relations between health professionals at work. This topic is so ambiguous that it seems to lead to confusion, even deliberate misinterpretations. However, this ambivalence has to be explained because it provides a forum where the themes and arguments presented can be considered and can be found in the very existence of organizations and institutions where these meetings take place. Public power is present in many forms: legislative and political, legal and administrative. The same can be said for the sciences. They exist in their own right or, very often, are represented by a group of experts that either takes a stand or is consulted in order to contribute to actions or decisions. This is how the debate developed over time and will, for the purposes of the present overview, provide us with some reference points and markers.

\section{Risks -the Preliminary Stages (Early 19th Century)}

From the end of the $18^{\text {th }}$ century onwards, the manufacturing boom presented its own set of problems -adverse effects to the environment and issues relating to working conditions. Some medical officers, especially in Paris, started to argue that it was the workers' own lifestyles and the general urban insalubrity (11) (as opposed to the industrial establishments they worked in) that were responsible for the harmful effects of occupational hazards. This was the opinion expressed by the founders of the Annales d'hygiène publique (Annals of Public Health) review and was largely the angle taken by Louis-René Villermé, himself a co-founder of the review. Commissioned by the "Académie des sciences morales" (Academy of Moral and Political Sciences) to produce a report on the highly controversial public issue of child labour, he conducted his well-known investigation into the workers' condition. In this he denounced the misery that comes from low wages, blaming excessive working hours and the inevitable exhaustion, as well as insalubrious housing and the absence of general good health. However, he did not fail to point out that that the introduction of machinery was a factor of progress and spoke out strongly against the amorality and alcoholism that were corrupting workers' lives. The criticism was selective and the psychosocial aspects were often put down to working conditions and the workers' lifestyles, ruling out the role of the manufacturing units: "it is

(11) Le Roux T. (2011), Le laboratoire des pollutions industrielles, Paris, 1770-1830, Paris, Albin Michel. indirectly $[\ldots]$ the eating habits, housing, fatigue, working hours, mores, etc., of workers that determine whether professional activity will affect (for better or worse) their health or that of their family. This should be considered as a general rule." ${ }^{(12)}$ This position implied that improvement of workers' health would be achieved through industrial progress, wage increase and social legislation. This way, the specific aspects of a profession were not questioned and the idea that certain "damage" factors (today considered to be psychosocial) for extra-professional reasons is introduced.

The notion of external factors requires further thought. The dependence of workers at the time on their employers was the norm and often brutal. However, this was not yet a salary-based system of subordination. Employers were still generally paying for the work based on a "haggling" system and mostly tended to take on hired labourers. (13) These hired labourers were in charge of getting their own team together, or handing out the work to other casual workers. This in turn led to the muchmaligned "sweating system" that appeared at the beginning of the $19^{\text {th }}$ century (its most excessive forms were curtailed in $1848^{(14)}$ ). Furthermore, the tribunals arbitrating or judging disputes concerning physical injury to workers often considered that the payment for the work included occupational risks and it was up to those carrying out the work to evaluate this risk. Conflicts arising from the introduction of machines revealed that workers often claimed that the operation of these machines and the ensuing hardship ${ }^{(15)}$ were an essential part of the job. The slow increase in the authority of supervisory staff and the value of work contracts illustrate the gradual development of salary-based subordination. Archive data (in particular the collections dedicated to labour issues in the departmental archives as well as the legal and crime series in the national archives) can surely give us a different angle, clearly pointing to employer responsibility and workers' dependence. At the time, the public authorities did not deem it useful to introduce general legislation in favour of protecting workers, whereas laws aimed at protecting women and children at work were gradually enhanced.

(12) Villermé L.-R. (1840), Tableau de l'état physique et moral des ouvriers, Paris, Renouard, Paris republications, EDI éditions, 1989, p. 52.

(13) Motrez B. (1966), Systèmes de salaire et politiques patronales. Essai sur l'évolution des pratiques et des idéologies patronales, Paris, CNRS éditions.

(14) Barraud de Lagerie P. (2012), "Le salaire de la sueur: un éclairage socio-historique sur la lute anti-sweatshop", Sociologie du travail, vol. $54, \mathrm{n}^{\circ} 1$, pp. 45-69.

(15) J ARRIGE F. (2010), "Le travail de la routine : autour d'une controverse sociotechnique dans la boulangerie française du $\mathrm{XIX}^{\mathrm{e}}$ siècle", Annales. Histoire, sciences sociales, vol. 65, $\mathrm{n}^{\circ}$ 3, pp. 645-677; Jarrige F. (2009), Au temps des "tueuses de bras". Les bris de machines à l'aube de l'ère industrielle, Rennes, Rennes University Press. 
Echoing Villermé's viewpoint, many companies adopted a paternalist approach in order to avoid the risks of moral corruption and fatigue. This was done by selecting their workers on the basis of their presumed morality and health. Pre-empting the law, these companies restricted physical labour in many cases, especially for children. At the same time, companies set up "recommendation networks" for recruiting its workforce. In certain areas of the countryside around Lyon, clerics acted as intermediaries with Christian textile company owners. ${ }^{(16)}$ This recommendation system was only the beginning of a solution that would resurface in later years. In the interwar period and after World War II, there would be an enquiry about moral or social behaviour here, or a request for guarantee from a current employee there ${ }^{(17)} \ldots$ Known -depending on the time- as either sponsorship solutions and later as paternalism, certain companies set up different systems aimed at attracting applicants and keeping, managing, recruiting, structuring and organizing their employees. ${ }^{(18)}$ It is worth noting however that action taken in this respect varied considerably because of the different objectives and needs of companies on one hand and the local or economic conditions at the time on the other.

\section{Changes of Perspective in La Belle Époque (the "Good Old Days")}

Varied research and verbatim statements from different players provide insight into the change of perspective that came about in the final decades of the $19^{\text {th }}$ century.

\section{The Question of Overwork (the 1900s)}

In her thesis on the wave of labour strikes between 1871 and 1890, Michelle Perrot analyses the demands of the strike movements obtained from research into departmental and national (mostly police and legal

(16) LEQUIN Y. (1977), Les ouvriers de la région lyonnaise dans la seconde moitié du XIXe siècle (1848-1914), 2 volumes, Lyon, Lyon University Press.

(17) Moutet A. (1997), Les logiques de l'entreprise. La rationalisation dans l'industrie française de l'entre-deux-guerres, Paris, EHESS éditions; HATzFELD N. (2002), Les gens d'usine. 50 ans d'histoire à Peugeot-Sochaux, Paris, Atelier éditions; VINDT G. (2006), Les hommes de l'aluminium. Histoire sociale de Péchiney, 1921-1973, Paris, Atelier éditions; Fourrier P., (2008), "Le travail des générations : confronter des présents décalés", in Arborio A.-M. et al. (ed.), Observer le travail. Ethnographie et histoire, approches combinées, Paris, La Découverte, pp. 113-129.

(18) GuesLIN A. (1992), "Le paternalisme revisité en Europe occidentale (seconde moitié du XIX ${ }^{\mathrm{e}}$, début $\mathrm{XX}^{\mathrm{e}}$ siècle)", Genèses, n 7, pp. 201-211; NoIrIEl G. (1988), "Du 'patronage' au 'paternalisme' : la restructuration des formes de domination de la main-d'œuvre ouvrière dans l'industrie métallurgique française", Le mouvement social, $\mathrm{n}^{\circ} 144$, pp. 17-35; DeBOuZy M. (ed.) (1988), "Paternalismes d'hier et d'aujourd'hui", Le Mouvement social, $\mathrm{n}^{\circ} 144$. departments) archives. (19) Remuneration issues, at the heart of two thirds of the demands were clearly the key issue, while excessive working hours or the difficulty of particular occupations accounted for a quarter of the reasons for the strike motivations, the rest tallying with some other claims. However, issues concerning productivity or overwork were rarely openly contested. The situation, as depicted by militant trade unionists, was somewhat different at the end of the $19^{\text {th }}$ century. Exhaustion and overwork came in for union criticism as reported by, for example, the Bonneff and Pelloutier brothers. (20) Presenting various professional situations, such as work in the steel or textile industries, the authors exposed the practice of piecework, which forced the workers to significantly increase their efforts and neglect elementary safety precautions. They also blame the "sweating system"; a form of outsourcing that prevailed in the clothing industry, quoting the report of a (female) work inspector who described the (female) workers observed as "victims of truly inhumane overwork." (21) These women working at the end of the assembly line were the ones who bore the brunt of the pressure coming from the top. ${ }^{(22)}$ In her study of the history of the clothing industry in Paris and New York over a century, Nancy Green points out all the different situations in this field of work to which the "sweating system" and non-stop turnover methods can be adapted, even today. ${ }^{(23)}$ The idea of overwork started to gain momentum among the unions, social reformers and certain pioneers in the physiology of work. (24) One such pioneer, Armand Imbert, highlighted the fact that work itself was an essential source of fatigue and mortality among workers, clearly moving away from the position of some of his fellow medical officials who continued to blame living conditions outside of work, especially the lack of decent housing and alcoholism. (25) The notion of mental fatigue and physical overwork drew attention from the field

(19) Perrot M. (1974), Les ouvriers en grève, France 18711890, Paris-La Haye, Mouton, Paris republication, EHESS éditions, $2^{\text {nd }}$ tome, pp. 260-261.

(20) Bonneff L., Bonneff M. (1908), La vie tragique des travailleurs, Paris, Jules Rouff éditions, Paris, EDI republication 1984 , p. 41

(21) Idem, p. 89, 209, 218; Pelloutier F. and M. (1900), La vie ouvrière en France, Paris, Schleicher Brothers Editors, republication Paris, François Maspero, 1975.

(22) Avrane C. (2010), Les ouvrières à domicile en France, de la fin du XIXe siècle à la Seconde Guerre mondiale. Genèse et application de la loi de 1915 sur le salaire minimum dans l'industrie $d u$ vêtement, thesis of contemporary history, University of Angers.

(23) Green N. (1998), Du sentier à la 7e avenue. La confection et les immigrés. Paris-New York 1880-1980, Paris, Le Seuil, pp. 189-222.

(24) Le Bianic T. (2004), "Le Conservatoire des arts et métiers et la 'machine humaine'. Naissance et développement des sciences de l'homme au travail au Cnam (1910-1990)", Revue d'histoire des sciences humaines, $\mathrm{n}^{\circ} 11$, pp. 184-214.

(25) Le Bianic T., Vatin F. (2007), "Armand Imbert (18501922), la science du travail et la paix sociale", Travail et emploi, $\mathrm{n}^{\circ} 111$, pp. 7-19. 
of psychology. (26) Generally speaking, research on the subject mainly focused on schools, universities and the armed forces, barely touching on work situations. They tended to associate mental tension or neurasthenia with either the constraints of modern living or hereditary characteristics. Certain specialists, however, did link fatigue with material living conditions and the preoccupations of lower-income categories: "Workers who stay up until midnight after a cheap meal of fried potatoes and a slice of sausage wear themselves out extremely quickly." (27)

\section{Intensification of Work -a New Threat}

Changes in work organization and wage relations led to criticism from trade unions. The influx of engineers into the industrial world and the headway they made with the rationalisation methods they developed, the widespread increase of machines and use of steam energy, plus the developments of shop floor skills all went handin-hand with changes to work contracts, which Alain Cottereau studied from the well-furnished and alas under-used archives of the prud'hommes (labour law) tribunals. ${ }^{(28)}$ To give a rough idea, up to then, more work meant working longer hours and exhaustion was inevitable in the long run. One result of these changes was the increasing application of the "intensification of work" principle. Thanks to the engineers' work, this was a time when technical changes were combined with remuneration systems, resulting in increased effort and heightening of tensions. At the same time, new remuneration systems consolidated the concepts of a salary system and a relationship of subordination (hierarchical constraints). The denunciation of the Taylor system by Emile Pouget in 1913 contained a section that referred directly to current cases of pathogenic situations on a psychosocial level. (29) This trade unionist was very critical of the presentation given by Taylor himself of one of his assignments at a testing centre. In this environment, (female) workers overcame the monotony of the tasks they meticulously performed thanks to an atmosphere of cheerful camaraderie. Taylor separated them and transformed the workshops

(26) Rabinbach A. (2004), Le moteur humain. L'énergie, la fatigue et les origines de la modernité, Paris, La Fabrique éditions, p. 556 (The Human Motor: Energy, Fatigue and the Origins of Modernity, New York, Basic Books, 1990).

(27) Deschamps A. (1908), Les maladies de l'énergie: les asthénies générales, épuisements, insuffisances, Paris, Alcan, 1908. Cited by Anson Rabinbach, Le moteur humain ... op. cit., p. 274.

(28) Cottereau A. (2002), "Droit et bon droit. Un droit des ouvriers instauré puis évincé par le droit du travail (France, $\mathrm{XIX}^{\mathrm{e}}$ siècle)", Annales. Histoire, sciences sociales, vol. 57, n 6, pp. 1521-1557; Chalmin C., Jarrige F., "L'émergence du contremaître. L'ambivalence d'une autorité en construction dans l'industrie textile française (1800-1860), Le Mouvement social, $\mathrm{n}^{\circ} 224$, pp. 47-60.

(29) Pouget E. (1913), L'organisation du surmenage (le système Talor), Paris, Marcel Rivière, pp. 43-50. into something resembling a labour camp, where a "gloomy and depressing silence" prevailed. $\mathrm{He}$ created "a legion of accountants, instructors and testers whose mission was to relentlessly track down any signs of a relaxed and leisurely attitude on the part of the [female] workers". He set a daily task, which could only be done by workers with enough strength and stamina to work for a much longer time than average "to earn twice as much as they were earning before, for a job that was three times as good, but ten times more tiring!" Comparing Taylor's method with that of Gilbreth, Pouget insisted on the absence of a real simplification of work and on the essential criteria of selecting workers based on their reflexive and psychological aptitudes. The same criticism was clearly echoed during the first French strike at Renault the same year protesting against timekeeping and the Taylor systems. ${ }^{(30)}$

The development of workers' organizations and trade unions activity contributed to the widespread increase in the number of these objections and protests. Archive collections, stored for early periods at the national and departmental Archives, at the Musée social or at the Centre d'archives $d u$ monde $d u$ travail (in Roubaix, France) provide data on these aspects. However, we need to clarify the scope and form of research into overwork. For example, rationalization procedures ${ }^{(31)}$ were introduced into certain sectors of the services industry, such as women's office jobs in large organizations. Ignoring the alarm signals for exhaustion and overwork, of which psychological disorders are just one part, physiologists were more interested in the restrictive notion of fatigue at the beginning of the $20^{\text {th }}$ century. At the Cnam (Conservatoire national des arts et métiers), for example, they chose to focus essentially on analysing energy consumption and the yield of muscular effort. ${ }^{(32)}$

\section{Workers' Health: the Beginnings of Legislation (End of the 19 $9^{\text {th }}$ Century)}

Finally, as a result of both public debates and input from different social players, ${ }^{(33)}$ the end of the $19^{\text {th }}$ century saw the introduction of some form of legislation governing workers' health. For decades, as we have already seen, certain

(30) Hatry G. (1971), "La grève du chronométrage (19121913)", De Renault Frères constructeurs d'automobiles à Renault Régie nationale, $\mathrm{n}^{\circ} 3$, pp. 73-81; FrIDENSON P. (1987), "Un tournant taylorien de la société française (1904-1918)", Annales. Economies, sociétés, civilisations, vol. 42, $\mathrm{n}^{\circ}$ 5, pp. 1031-1060.

(31) GaRdey D. (2001), La dactylographe et l'expéditionnaire. Histoire des employés de bureau, 1890-1930, Paris, Berlin.

(32) Vatin F. (1999), Le travail, sciences et société. Essai d'épistémologie et de sociologie du travail, Brussels, University of Brussels éditions.

(33) Cohen Y. (1998), "Lorsque le facteur humain paraît (18901920) : esquisse de l'histoire d'une préoccupation collective", La Lettre de la maison française d'Oxford, $\mathrm{n}^{\circ}$ 9, pp. 59-78. 
companies had been trying to use doctors' services and demonstrated their interest in the health of their employees, provided it was in keeping with their activity. ${ }^{(34)}$ From 1860 onwards, health officials started looking more keenly into work-related illnesses. A few years later, faced with growing protests from workers, both the industry and employers started to consider setting up a system for fixing the amounts of compensation paid out to victims of accidents at work. Finally, in the 1880s the debate on prevention and compensation went public. The laws voted in 1893 concerning prevention and in 1898 concerning the compensations of work-related accidents marked the beginning of a new policy for workers' health. This legislation formed the as yet modest foundations of a regime providing fixed compensation for victims of workrelated accidents. However, it was only in 1919 that workers with one or two specific occupational illnesses became entitled to compensation -lead poisoning and mercury poisoning-both chosen due to their undeniable occupational origin. In order to apply the law of 1893 on risk prevention, the State set up a work inspection service. (35) However, the resources directly provided for this service were very limited and the companies themselves took on a large part of responsibility for workers' health, while at the same time limiting the scope of the legal liability relating to this responsibility. (36)

\section{From One War to Another -Ups and Downs}

Between 1914 and 1944, a series of major crises revealed often-implicit links between external and internal risk factors. The course followed by social actors, political forces and public authority did, however, follow a kind of logical progression.

\section{Reform Breakthrough and Management-Led Offensives}

During the First World War, exceptional employment conditions made life even harder for workers in many respects. This was due to the massive deployment of the colonial and female workforce

(34) Moriceau C. (2009), Les douleurs de l'industrie ... op. cit., pp. 176-180.

(35) VIET V. (1994), Les voltigeurs de la République. L'inspection du travail en France jusqu'en 1914, Paris, CNRS éditions.

(36) Bruno A.-S., Geerkens E., Hatzfeld N., Omnes C. (2011), "La santé au travail. Regards comparatistes sur l'historiographie récente", in BRUNO A.-S. et al. (ed.), La santé au travail, entre savoirs et pouvoirs (XIXe-XXe siècles), Rennes, Rennes University Press, pp. 13-40. and the rationalization of mass production. ${ }^{(37)}$ At this time, the development of the "skilled worker" category reflected employers' position concerning putting unskilled workers on machines designed for professionals. ${ }^{(38)}$ These changes came in addition to the generally difficult living conditions linked to the war effort and were reflected in the strike movements of 1917. (39) However, once he took on his governmental responsibilities, Albert Thomas took steps to structure, guide and reward the unprecedented efforts required by this redefined world of work. Research into factory superintendents showed the significant yet limited role of risk management ${ }^{(40)}$ and archives still offer resources for further analysis of this policy. Yet, this historical research into labour barely touches on the different aspects of social situations in this period and the interwar period. Other research reveals the development of reform concerns, as much in political circles as among lobby groups and networks and national and international authorities. ${ }^{(41)}$

The 1920s saw the development of Americanstyle rationalization methods. Its application was highly selective, both in terms of the number of companies that resorted to them and the restricted choice of the methods to be used. Working conditions became increasingly harsh during the 1930 crisis and this was fuelled by the fear of unemployment, as was reflected by the significant reduction in labour unrest. Many companies changed their payment rates, forcing workers to work more for the same money ${ }^{(42)}$ and the pressure they put on employees could reach almost unacceptable levels. ${ }^{(43)}$ The inevitable tensions are, in the current state of historical research on this period, analysed in general terms.

(37) Cohen Y. (2001), Organiser à l'aube du taylorisme. La pratique d'Ernest Mattern chez Peugeot, 1906-1919, Besançon, Franche-Comté University Press, pp. 195-430; Downs L. L. (2001), L'inégalité à la chaîne. La division sexuée du travail dans l'industrie métallurgique en France et en Angleterre, Paris, Albin Michel.

(38) Machu L. (2011), Les conventions collectives du Front populaire. Construction et pratiques du système français de relations professionnelles, thesis in History, University Paris Ouest-Nanterre.

(39) Dubesset M., Thebaud F., Vincent C. (1977), "Les munitionnettes de la Seine", in Fridenson P. (ed), 1914-1918, l'autre front, Paris, éditions ouvrières, pp. 189-219; MOUTET A. (1992), La rationalisation industrielle dans l'économie française au XXe siècle. Étude sur les rapports entre changements d'organisation technique et problèmes sociaux (1900-1939), $\mathrm{PhD}$ thesis in History, University Paris 10-Nanterre.

(40) Fourcaut A. (1982), Les femmes en usine, Paris, Maspero. (41) Chatriot A., Join-Lambert O., Viet V. (ed.) (2006), Les politiques du travail (1906-2006). Acteurs, institutions, réseaux, Rennes, Rennes University Press; Lespinet-Moret I., VIET V. (ed.) (2011), L'Organisation internationale du travail, Rennes, Rennes University Press.

(42) Moutet A. (1997), Les logiques de l'entreprise. La rationalisation dans l'industrie française de l'entre-deux-guerres, Paris, EHESS éditions, pp. 304-320.

(43) Omnes C. (1997), Ouvrières parisiennes: marchés du travail et trajectoires professionnelles au $X X^{e}$ siècle, Paris, EHESS éditions. 
Working conditions during the Vichy Regime and under the Occupation also come in for similar treatment by historians. And yet there was no shortage of constraints, surveillance, threats and deprivation and this put salaried workers in unbearable situations. In certain areas, accelerated exhaustion levels were recorded (railroad and Billancourt workers, for example) whereas in certain hospitals the term "distress" was used. (44) The miners held a strike protesting against performance-related pay on caseby-case basis. But it was later on in the weeks and months following the liberation of France that the traumatizing consequences of this period became apparent. In several sectors of activity, such as mining or the metal industries, the workers did not excuse the harshness of their bosses (namely, their behaviour or their demands on their subordinate employees) on the sole grounds of German-inflicted pressure. Thus requests for "purging" supervisory and management staff were not only aimed at collaborators -workers also demanded that an end be put to bullying and other aberrations in the workplace. We still do not fully know to what extent this unbearable level of working conditions was maintained during the post-war construction years. Fully involved in the "battle for production", the head of the Communist Party deplored a "moral crisis" in the working world. ${ }^{(45)}$ The uncontrollable strikes in the industry and mining sector protesting against this rise in prices in 1947 and 1948 contributed to the shift in communist policy.

In these troubled times, legislation and regulations concerning health at work were reinforced, as can be seen by the increase of professional illnesses entitled to compensation and the creation -in stages spanning the latter years of the $4^{\text {th }}$ Republic to the Liberation, including the Vichy Regime- of occupational medicine and committees for health and safety. ${ }^{(46)}$

\section{Occupational Psychology: Theoretical and Technical Outlines}

Occupational psychology developed autonomously during this period, notably at the Cnam and the EPHE (École pratique des hautes études). Even if the political and institutional supervisory bodies did not always distinguish this activity from the Taylor model, the leaders in the field clearly distanced themselves from that movement, as they

(44) Peschanski D., Robert J.-L. (ed.) (1992), Les ouvriers en France pendant la Seconde Guerre mondiale, Paris, IHTP, supplement to Cahiers $\mathrm{n}^{\circ} 20$.

(45) Vigna X. (2012), Histoire des ouvriers en France au XX siècle, Paris, Perrin, p. 167.

(46) DevincK J.-C. (2002), "La création d'une médecine du travail en France, 1914-1946", Cahiers du centre fédéral, $\mathrm{n}^{\circ}$ 36, UNSA; Buzzi S., Devinck J.-C., Rosental P.-A. (2006), La santé au travail, 1880-2006, Paris, La Découverte. wanted to focus essentially on worker health. ${ }^{(47)}$ In contesting, as Jean-Paul Langlois did, the quest for maximum yield, Jean-Maurice Lahy tried to understand the mental activity of certain professions, such as typists, tramway conductors and typesetters. Starting with field studies on these, he gradually moved towards creating aptitude indicators and ended up designing tests. Used for hiring a specific category of employee, these tests proved their worth in the recruitment process. Combined with medical visits, they made it possible to eliminate applicants likely to be unsuitable for the job vacancy in question. Renault was one of the companies that used these tests to eliminate professional workers on the basis of their unsuitability for the job and the potential risk of an accident at work. For Michelin however, morality remained an explicit selection criterion. (48) However, these new approaches were only rarely (and belatedly) fully adopted during the first half of the century. One of the main explanations is the lack of personnel departments in the majority of companies: they just about managed to set up medical visits at the time of recruitment. ${ }^{(49)}$ The role of factory social workers did not really develop; somewhere between social assistance and maintaining order, their role is a subject for debate among historians. (50) Other "social technicians" emerged, notably following the strike of 1936. ${ }^{(51)}$ The field of psychotechnics underwent further change when the Carrard method was included in professional training from the end of the 1930s, replacing traditional learning approaches. ${ }^{(52)}$ However, alongside this practical development of the discipline, Édouard Toulouse created the Ligue d'hygiène mentale (Association of Mental Health) and its aim was to study and prevent mental disorders, particularly in educational and professional situations. ${ }^{(53)}$

(47) Vatin F., Le travail, sciences et société ..., op. cit. ; LE BIANIC T., "Le conservatoire des arts et métiers ...", op. cit. (48) Frader L. L., Sofio S., "Depuis les muscles jusqu'aux nerfs : le genre, la race et le corps au travail en France, 19191939", Travailler, $\mathrm{n}^{\circ} 16,2006 / 2$, p. 111-144.

(49) Moutet A., Les logiques ... op. cit., p. 151; FombonNe J. (2001), Personnel et DRH. L'affirmation de la fonction Personnel dans les entreprises (France, 1830-1990), Paris, Vuibert.

(50) Downs L. L. (2001), L'inégalité à la chaîne. La division sexuée du travail dans l'industrie métallurgique en France et en Angleterre, Paris, Albin Michel; OMNEs C. (2009), "Les surintendantes d'usine. Attention au 'facteur humain' et prévention du risque au travail (1917-1946)", in Omnes C., PITTI L. (ed.), Cultures du risque au travail et pratiques de prévention. La France au regard des pays voisins, Rennes, Rennes University Press, pp. 19-30.

(51) Cohen Y. (1996), "L'invention des techniciens sociaux. Du commandement social après juin 1936 chez Peugeot", Actes de la recherche en sciences sociales, $\mathrm{n}^{\circ} 114$, pp. 30-43.

(52) Hatzfeld N. (1989), "L'école d'apprentissage Peugeot (1930-1970) : une formation d'excellence", Formation emploi, $\mathrm{n}^{\circ}$ 27-28, pp. 115-130.

(53) Billiard I. (2001), Santé mentale et travail. L'émergence de la psychopathologie du travail, Paris, La Dispute. 


\section{The Post-War Productivity Boom (Les Trente Glorieuses)}

The post-war period was known for its systemic mind-set, in terms of rationalization of work, attempts to avoid risks by companies and the institutionalization of occupational health.

\section{Productivity as a Leitmotiv}

The period following the reconstruction of France saw a massive and widespread introduction of rationalization of work, fuelled by productivity projects. At the same time, there was a growing number of engineers, technicians and other timekeepers in most large companies, as well as a proliferation of consulting organizations. For the world of work this was the glorious era of Organization and Methods departments, job analyses and the simplification of work. Initially started in workshops, the movement was extended to the service sector, especially to offices. Pools of typists and stenographers increased in number and also underwent similar changes, as we can see from the parody in Jacques Tati's film Jour de Fête. ${ }^{(54)}$ From a trade-union point of view, the CGT (Confédération Générale du Travail or General Confederation of Labour) denounced in the 1950s the intensification of work which caused "at the same time physical fatigue and nervous fatigue, infinitely more dangerous", as metal workers put it. (55) Going further, trade unionists in the French post office and telecommunications services tried to have nervous fatigue recognized as an occupational illness linked to productivity. ${ }^{(56)}$ Psychiatrists, including Louis Le Guillant, worked with them and studied nervous fatigue caused by different occupations, especially that of telephone operators. ${ }^{(57)}$ These psychiatrists were not the only ones in the medical field concerned by this problem, as different occupational health publications also covered

(54) Guigueno V. (1995), “L'écran de la productivité : 'Jour de fête' et l'américanisation de la société française", Vingtième siècle. Revue d'histoire, $\mathrm{n}^{\circ} 46$, pp. 117-124; JOIN-LAMBERT O. (2003) "Histoire du service médical des PTT (1943-1977)", Travail et emploi, $\mathrm{n}^{\circ}$ 96, pp. 105-119.

(55) Hatzfeld N. (2005), "Les syndicats de l'automobile aux congrès fédéraux: un modèle renouvelé (1948-1963)" in Bressole E., Dreyfus M., Hedde J., Pigenet M. (ed.), La CGT dans les années 1950, Rennes, Rennes University Press, pp. 35-47.

(56) Joln-Lambert O. (2001), “Au nom du rendement. L'invention de l'inaptitude aux PTT entre 1944 et 1958", Revue de l'IRES, $\mathrm{n}^{\circ} 37$, p. 134.

(57) Le Guillant L. (2006), Le drame humain du travail. Essais de psychopathologie du Travail, Toulouse, Eres, (presentation of Yves Clot) ; Loriol M. (2006), "Ennui, stress et souffrance au travail" in Alter N. (ed.), Sociologie du monde du travail, Paris, France University Press, pp. 226-245. this issue. (58) In 1960, fatigue was chosen as the main theme of the National Occupational Health Meeting and created substantial findings, some of which focused on the nervous and psychological aspects of fatigue. ${ }^{(59)}$ During the 1960s, the CFTC (Confédération Française des Travailleurs Chrétiens or French Confederation of Christian Workers) which became the CFDT (Confédération française démocratique du travail or French Democratic Work Confederation) cooperated with ergonomists from the Cnam to gain more insight into nervous pathologies in new, modern and clean factories where workers specialized in household appliances were employed. ${ }^{(60)}$ This period reveals considerable concern regarding the psychological effects of the rationalization of work; these fears were not, however, generally subscribed to -the prevailing belief and confidence in modernism tended to block out these negative views. In company life, the widespread mobility of workers alleviated the "wages of progress" in particular those that took the form of psychological and nervous disorders (especially in the banking and insurance sectors) later denounced by the CFDT. ${ }^{(61)}$ The attention and the lack of attention given to these questions by trade unions is a subject meriting further research -the archive collections held by the major confederations can provide particularly valuable data. Paradoxically, the 1968 period, quite rightly known as "anti-establishment", tended to play down this criticism with, notably, the question of "mind-numbing production rates". ${ }^{(62)}$ However, the inclusion of hysterical fits in protest film scenes or accounts of the same in the women's CGT newspaper Antoinette show that there was increased awareness of the problem. ${ }^{(63)} \mathrm{As}$ is often the case, films, as well as literature and other forms of artistic

(58) Roques M. (1957), "États dépressifs chez des employés des services mécanographiques ou téléphoniques des PTT", Archives des maladies professionnelles, tome 18, pp. 52-53; Planques J., Garnier A. (1960), "Diagnostic des névroses du travail", Archives des maladies professionnelles, tome 21, p. 240; Laboucarie J.-M. (1960), "Observations de deux névroses de cadre", Archives des maladies professionnelles, tome 21, pp. 241-244.

(59) Soula C., Moynier R., Bourguignon C., Bourguignon A., Monod H. (1961), "Aspects musculaires, sensoriels, psychologiques et sociaux de la fatigue (1)", Archives des maladies professionnelles, tome 21, pp. 241-244.

(60) Laville A., Teiger C., Duraffourg J. (1972), Conséquences du travail répétitif sous cadence sur la santé des travailleurs et les accidents, final report $\mathrm{n}^{\circ} 29$, collection of the laboratory of occupational physiology and ergonomy of the Cnam, Paris, p. 385; TeIGer C. et al (2006), "Quand les ergonomes sont sortis du laboratoire ... à propos des femmes dans l'industrie électronique (1963-1973). Rétro-réflexion collective sur l'origine d'une dynamique de coopération entre action syndicale et rechercheformation-action", Pistes, vol. 8, n 2, p. 38 .

(61) CFDT (1977), Les dégâts du progrès. Les travailleurs face au changement technique, Paris, Le Seuil, pp. 85-131.

(62) Vigna X., L'insubordination ouvrière ..., op. cit., pp. $156-169$.

(63) Gallot F. (2009), "La crise de nerfs. De la souffrance à la résistance?”, Clio, n 29, 2009, pp. 153-164. 
expression, illustrate remarkably well how differently these issues can be perceived.

\section{Rationalizing Risk?}

In the second half of the $20^{\text {th }}$ century there was an upsurge in the systematic approach adopted to avoid exterior risks. Following on from previous initiatives, occupational health services became legally compulsory for companies employing more than 50 members of staff. However, their roles are still often restricted to pre-recruitment medical examinations and check-ups. Pre-recruitment examinations have been enhanced by psychotechnical elements that fine-tune the selection procedure, especially when it comes to reducing the risk of unsuitability for the required tasks. In companies with a high number of employees applicants were tested for attention and reflex skills, along with other psychological aptitudes and strong resistance to mental tension or effort. Doctors in large banks in the 1950s boasted about checking out typing pool applicants for nervous disorders. ${ }^{(64)}$ The same line was used ten years later for a large typing pool of a bank: "We insist on a medical examination for the following two points: stress resistance and state of the spine."(65) Once the hiring process was finalised, the medical services tended to deny any difficulties that later arose, to the point of blaming the disorderly lifestyle of the employees. In this case, it was supposedly young workers coming from the provinces dazzled by the bright lights of Paris and willing to neglect their own health. Another evasion tactic was to attribute depressive situations, frequent in certain professions, to nature. As an occupational health doctor wrote in a specialised review: "Women have always been known to be more 'nervous' than men and we don't know exactly what this 'nervousness' consists of. Drastic industrialization has brought a great number of women to factories, workshops and offices ... and they have brought their nervousness with them." (66) Finally, mobility often provided a solution (or at least a partial solution) to any difficulties encountered. This shows that reality is often far-removed from the initial intention, sometimes restated by certain large companies, which was to use appropriate recruitment procedures to find the right person for the right job.

(64) Neumann C. (2010), "Rendement et santé au travail des mécanographes (1945-1975)" in BrunO A.-S. et al. (ed.), La santé au travail, entre savoirs et pouvoirs (XIXe-XXe siècles, Rennes, Rennes University Press, pp. 86-87.

(65) Laporte A., Deplanque M. (1966), "Étude comparée de deux groupes de travail en commun 'groupe dactylos'-'groupe perforeuses' attachés à un atelier mécanographique", Archives des maladies professionnelles, tome 27, pp. 87- 89.

(66) Chabrier A. (1966), "La 'dépression nerveuse' chez la femme au travail", Archives des maladies professionnelles, tome 27, pp. 72-74.

\section{Staff Consultation Committees - Promising Institutions?}

The institutionalization of occupational health ensured the prospect of care for employees, despite a certain ambivalence mentioned above. Even though a large part of their activity consisted in pre-recruitment medical examinations and check-ups, doctors also had to closely monitor prevention of risks that doing a job involved. As limited as it may have been and largely disowned by the State, occupational health was no longer the only means applied in the field of prevention. Indeed, in addition to the safety services implemented at the employers' discretion, the first forms of worker representation in this domain started between 1940 and 1945 with the forming of factory health and safety committees. Forty years later, these would become the committees for health, safety and work conditions (CHSCT) that we know today. For many years, work inspectors have been lamenting the weaknesses of these organizations that, in their opinion, provide only mediocre leverage for action, and even then, not what they were hoping for. ${ }^{(67)}$ The limited administrative scope of their action added to this subdued existence, as did the half-hearted involvement of most union organizations during this era. Whatever assessment these organizations deserve, they still offer an underexploited wealth of research on the questions of occupational health.

Measures undertaken by the Ministry of Employment in terms of organization, work conditions and occupational risks began to change during the 1960s, following the first directions adopted by the brand-new European Community, which was pushing for closer cooperation between national compensation and prevention systems. ${ }^{(68)}$ Until that point, the ministry had shown systematic resistance in terms of the recognition of occupational diseases such as peri-articular disorders. Faced with increasingly urgent requests from the Social Security system to increase the number of recognized illnesses, the management of the Ministry finally agreed the inclusion of certain requests in the agenda. ${ }^{(69)}$

(67) Hatzfeld N. (2007), "Entre fonction technique et démocratie participative, les débuts discutés des CHS (19471970)", in Chatriot A., Join-Lambert O., Viet V. (ed.), Les politiques du travail ..., op. cit., pp. 403-414.

(68) Hatzfeld N. (2012), "La construction européenne et les maladies professionnelles: l'impulsion sociale des années 1960" in Courtet C., Gollac M. (ed.), Risques du travail, la santé négociée, Paris, La Découverte, pp. 51-64.

(69) JoIn-LAmbert O. (2012), "Administrations du travail", in Bevort A., Jobert A., Lallement M., Mias A. (ed.), Dictionnaire du travail, Paris, France University Press, pp. 12-19. 


\section{The Emergence of the Notion of Psychosocial Risks (Between 1980 and 2000)}

Several factors came into play from the 1980s onwards, transforming the world of work. It is worth mentioning opportunities for employees and their representatives to voice their criticisms and also new concerns regarding growing risk voiced by other professionals from the health sector.

\section{A New Work Crisis and the Increased Role of Expertise}

Computerization of organizations started in the banking and insurance sectors. Its rapid development was behind many other changes, making information accessible and providing the means for unprecedented coordination, evaluation and testing procedures. ${ }^{(70)}$ Among these other changes, we can mention the "quality" movement (which combined employee involvement and tighter control of employees), the legal fragmentation of activities via outsourcing and their technical integration reinforced by JIT (just in time) and "leaning" strategies. The deterioration in working conditions, the increase in instability, the pressure of unemployment and reduced regulation due to professional mobility -all these highlight the impact of the demanding, even aggressive management strategies which were becoming more widespread. Faced with the reduction of two of the basic possible responses to decline in firms, namely "exit" and "voice" (the ability to leave a job and to voice an opinion), as defined by Albert Hirschman, ${ }^{(71)}$ employees experienced situations which in many sectors could be described as work crises.

In this context, institutional reforms favoured the voicing of criticism from employees and their representatives, while different players in the health sector were increasingly focused on the increase and development of risks affecting workers' mental and nervous health. The institutions and organizations responsible for health care in companies were supported by measures taken by the State and were able to find different solutions coming from outside their own organizations.

One form of support concerns epidemiology, which benefits from increasingly powerful computerbased resources that provide more finely-tuned analyses. This has contributed to the development of multi-factorial analyses based on questions coming from clinical analysis. In the case of psychosocial risks, like many other multi-factorial pathologies, the combination of different aspects has often had a

(70) CFDT (1977), Les dégâts du progrès..., op cit.

(71) Hirschman A. (1995), Défection et prise de parole: théorie et applications, Paris, Fayard, ( $1^{\text {st }}$ edition 1972), p. 212. negative impact on how the question is approached. There has been too much uncertainty concerning aspects that are too difficult to identify conclusively, both in terms of statistics and clinical analysis. Headway made in epidemiology has made it possible to confirm and measure the effect of internal factors in the world of work, without necessarily excluding other external factors. We can see the beginnings of a coexistence of different viewpoints. Hélène Sultan-Taïeb and Isabelle Niedhammer confirm this in their article in this edition (originally published in Travail et emploi $\mathrm{n}^{\circ} 129$ ), where they introduce the method of attributable fractions. In fact, we can see occasional interdisciplinary cooperation, as the jointly written critical review in 1985 devoting several pages to psychological suffering and depression (72) proves. The "Société d'ergonomie de langue française" (French language Society of ergonomics), which donated its records to the departmental archives at Bobigny, is another example of this type of cooperation.

This progress in terms of scientific approach is a response to increasing institutional needs. Throughout most of the $20^{\text {th }}$ century, public policy seemed to consist of delegating a large part of occupational health issues to the companies and organizations themselves. However, from the 1960s onwards this approach was reconsidered. Later, there was much more discussion concerning the balancing of social welfare accounts, an issue which had not been clearly stated during the period of strong economic growth. The General Social Security system's difficulties brought up further questions about the extent to which professional pathologies should be covered by the State. Discussion of this issue was further fuelled due to the transfer of certain elements from the Occupational Accident and Illness branch to the main body of the Social Security system.

At the same time, the growth of European Economic Community contributed to a rethinking of what had until then been considered obvious in the French organization of occupational health policies. For almost a century, the International Labour Organization (Organisation Internationale $d u$ Travail, OIT) has played a role in this area by providing opportunities to meet, momentum for research and reform, as well as incentives legitimized by its international status. ${ }^{(73)}$ The organization acts as a type of diplomat in the working world and, over and beyond simple meetings of experts, it endeavours

(72) Cassou B., Huez D., Mousel M.-L., Spitzer C., Touranchet A. (ed.) (1985), Les risques du travail. Pour ne pas perdre sa vie à la gagner, Paris, La Découverte.

(73) CAYET T. (2010), Rationaliser le travail, organiser la production. Le Bureau international du travail et la modernisation économique durant l'entre-deux-guerres, Rennes, Rennes University Press; Moret-Lespinet I., Viet V. (ed.) (2011), L'Organisation internationale du travail. Origine, développement, avenir, Rennes, Rennes University Press. 
to influence national policies ${ }^{(74)}$ and encourages, on all levels, cooperation between the State, management and workers' unions. However, the scope of the ILO (also known as the Bureau International du Travail, BIT) is still limited -Europe has more influence. Although we are far from the prescriptive approach of the early years, the institutions of the European Economic Community (EEC) and subsequently the European Union (EU) has had more influence on French policy via the creation of incentives for member states. Thus, the 1989 European Framework Directive relating to the improvement of worker health and safety, which became law in France in 1991, made it clear that risk prevention was an obligation for employers. A decade later, this Directive was used as a basis for setting a legal precedent in the area of psychosocial risks. (75) Furthermore, French approaches and choices were influenced by comparisons among member States, the increasing importance of economic links and the willingness to equalise the Union's labour markets ${ }^{(76)}$. In the mid 2000s, France belonged to the last group of countries that did not recognize "stress" and also ranked among the countries producing the fewest solid empirical data on psychosocial risks. This is why the analyses, suggestions and achievements of Community bodies can hardly be ignored.

\section{Trade Unionism: a New Deal, New Trends?}

There is a consistency between social, scientific and institutional changes and changes in health and safety committees that merged in 1982 with the commissions on the improvement of working conditions, created in 1973 in large companies. The scope of CHSCT's authority on various aspects of work organization was extended. The same year, the "right to notify" was granted to CHSCT staff representatives, allowing them to immediately notify the employer if they became aware of a work situation presenting serious and imminent danger. This right goes hand-in-hand with the "right to leave" which allows employees in this kind of situation to interrupt their work. At the same time, unions now tend to pay more attention

(74) Cayet T., Rosental P.-A., and Thebaud-Sorger M. (2009), "How International Organisations Compete: Occupational Safety and Health at the ILO, a Diplomacy of Expertise", Journal of Modern European History, vol. 7, n 2, pp. 265-282.

(75) Adam P. (2008), "La prise en compte des risques psychosociaux par le droit du travail français", Le droit ouvrier, $\mathrm{n}^{\mathrm{o}}$ 710, pp. 313-332; Lerouge L. (2010), "Le droit du travail français confronté aux nouveaux risques. Quelle prise en compte de la santé mentale en droit du travail?", Revue multidisciplinaire sur l'emploi, le syndicalisme et le travail, vol. 5, no 2, pp. 21-38.

(76) Laflamme A.-M. (2008), La protection de la santé mentale au travail: le nécessaire passage d'un régime fondé sur la réparation des atteintes vers un régime de gestion préventive des risques psychosociaux, Thesis in Law, University of Laval, Québec, pp. 103-139. to occupational health issues than in previous years and the measures mentioned above provide them with new means of taking action. The CHSCT has a broader platform than before -perhaps because other institutions such as staff representatives and works councils (comités d'entreprise) seem to be losing ground. However, the focus these committees put on the issue of psychosocial risks can give rise to controversy and the findings can vary widely according from one study to another. Examination of EDF-GDF employee-management exchanges over the last few decades shows that the inclusion of psychosocial risks in discussions reflects a change -union-led protests about suffering and excessive constraints have developed into a questioning on the sources of these difficulties without excluding the risks that employees themselves can cause. (77) This controversy refuels the old debate about risk factors.

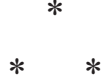

At the end of this deliberately broad and rapid historical overview, we can observe that the notion of psychosocial risks is no less complex and no less well defined. By focusing on the workers as people, this notion can, depending on differences in assessment and the balance of power, show the workers as both subjects of threat and as instigators of problems. This duality is not new and, if we go back two centuries, we can find evidence of both perspectives. Sometimes simultaneously, but not always, the two points of view presented are expressed in specific ways at a given time. For both of them, the arguments and practices have their own peculiarities, as do the players and institutions that these confrontations involve. Indeed, these two points of view are part of more complicated debates, which draw upon different scientific, social, and institutional aspects. These configurations always bring into play the links between the workplace and the space outside work, as well as the way in which social forces deal with this division. In particular, the focus is on the acceptable criteria levels in terms of hardship and difficulty at work. In this regard, the peculiarity of the recent period, torn between discordant interpretations and strengths, calls for a rethinking of former situations.
(77) Benquet M., Marichalar P., Martin E. (2010), "Responsabilités en souffrance. Les conflits autour de la souffrance psychique des salariés d'EDF-GDF (1985-2008)", Sociétés contemporaines, $\mathrm{n}^{\circ}$ 79, pp. 121-143. 